\title{
Preparing to Fight Unloved Wars
}

\author{
John J. Maresca ${ }^{1}$
}

The American response to the terrorist attacks of 11 September 2001 has given the world another glimpse of how the U.S. military will use its technological advantages to fight distant wars in the twenty-first century. The Pentagon is unlikely to withhold any new weapons systems from its operations against Osama bin Laden and the Al Qaeda network, because his terrorist attacks are seen as unprincipled aggression against the American nation. The tactics used appeared for the first time in the fighting in Bosnia and Kosovo, but those were more limited operations, without the use of ground forces, and some technologies deployed in Afghanistan were not used there. However, like the wars in former Yugoslavia and Somalia, the war waged over Afghanistan was an "unloved" war: Americans did not want to see their troops die in it. The lessons of such wars are many, relating to the entire continuum of warning, conflict termination, and reconstruction. All of these phases must be addressed in planning to face such conflicts, or they will not be won. America is steeling itself to fight such "unloved" wars, for these are the types of challenges the world's only superpower will face in the years ahead.

Since the end of the Cold War, the international community, particularly the United States, has increasingly been called upon to respond to conflicts where their essential national interests have been only marginally engaged. At the same time, there has been very little readiness among Western publics to sustain casualties in these conflicts. Engagement in such wars has simply not been considered essential for national survival and therefore not worth loss of life. The September 11 attacks changed this equation because, for the first time, such an "unloved" conflict was brought directly to the American homeland.

"Loved" wars are conflicts in which human sacrifice is seen as heroic and worthwhile. The Second World War was a "loved" war; we are still rapturously watching films that evoke the heroism and sacrifice of those who fought it. But wars that are distant from our national interests, or must be fought over issues to which Americans cannot relate, are not "loved." Losses of American lives are considered unjustifiable in such wars; these are other peoples' wars, even when they include direct attacks on Americans.

"Unloved" conflicts share a number of characteristics. They are local wars, fought in remote, unfamiliar regions. They are based on obscure ethnic rivalries and competing claims to territory, or on extreme and suicidal interpretations of scriptures that most Westerners do not understand. These conflicts are sustained

\footnotetext{
${ }^{1}$ John J. Maresca is President of the Business Humanitarian Forum and has focused on the role of business in post-conflict reconstruction. As a U.S. Ambassador, he was a negotiator and conflict mediator in the Caucasus and the Mediterranean region.
} 
by unsophisticated populations and legendary hatreds, and are fueled by quasifeudal warlords. They are set off by locally-important triggering events, and have occurred in recent years in the Balkans, the Middle East, the Caucasus, Southeast Asia, Central and South Asia, and Africa. Unfortunately, their potential for recurrence is relatively high, as impoverished peoples seek relief from their distress. And the new element, after September 2001, is that any of these local wars may have direct repercussions in the West.

These conflicts commonly threaten regional and even global stability, and therefore attract the attention of the industrialized world, which wants them controlled and contained. But outsiders rarely have more than a superficial understanding of the issues involved, and once they are engaged in such conflicts it is difficult for them to walk away, lest they leave the situation worse than they found it.

In addition, these conflicts are fought with savage ferocity. Rape, ethnic cleansing, suicidal terrorism, and wholesale destruction of towns, villages, and institutions have all been used as military instruments, and this comes at a time when the Western world seeks to avoid even minimal collateral civilian casualties in its approach to warfare. The suicide attacks on New York and Washington brought this type of warfare to America's doorstep - indeed, into its very living room.

There is not yet a world conflict management body to take the lead in responding to such conflicts. Such a body would need the powers of the UN Security Council combined with the values of the industrialized Western world and the military and technological capabilities of the U.S., and is unlikely to emerge any time soon. For the foreseeable future, effective response to such conflicts can come only from ad hoc coalitions of the willing, with a UN Security Council mandate and direct or implicit American leadership.

A combination of experience, technical advances, and new possibilities has given the international community the ability to respond to such conflicts or potential conflicts in ways that take into account diffident Western public attitudes. But planning must be comprehensive and based on the lessons we have learned. Another factor is that the United States has unique technical abilities, which are essential for the battlefield tactics needed to avoid taking numerous casualties, but is reluctant to share these technologies, even with close allies. This gap between American conflict-response capabilities and those of America's likely conflict coalition partners is steadily growing, and aggravates the differences in national perceptions that already surround almost any conflict. While the U.S. is racing toward ever more technologically-sophisticated weapons systems, its allies are focused more on human-scale techniques for peacekeeping and rehabilitation of war-torn local societies.

Effective response to "unloved" wars must take advantage of both technical advances and the human lessons learned in recent years. This mix must be woven 
into an integrated continuum of actions that respond in different ways to each phase of an emerging/evolving conflict. Each conflict is different, and responses must take account of specific factors, but in every case planning must address all phases of the conflict together, with specialized forces and abilities designated and made available in advance for each phase. This is the conflict-response continuum:

\section{Phase 1. Pre-conflict warning and engagement, and addressing the roots of conflict}

Forewarning. Detecting indicators of a nascent conflict before it occurs must be developed into a more accurate and comprehensive science, using indicators based on experience coupled with new technologies integrated into a system that provides information and analysis to national authorities and international structures on a close-to-real-time basis. The huge amounts of information that are routinely available need to be sifted efficiently; potentially related items need to be put together so that they become more meaningful; indicators and clues need to be shared internationally.

Developing political will to engage. More difficult than foreseeing conflicts is translating warnings of conflict into the political will to take action. To do this there must be new devices and channels for using warnings to stimulate discreet consultations, political awareness, decision-making power, and conflictprevention action. This is also the stage at which coalition-building must begin. Information sharing must be more complete and effective.

Reinforced conflict prevention. Conflicts cannot be prevented without some threat of forceful response to offset local pressures for confrontation. Wellintentioned diplomatic mediation alone is unlikely to forestall a desire for blood revenge. Conflict prevention efforts should be reinforced with meaningful penalties for aggressive behavior by warlords, and at least the implied threat of use of force. The involvement of the UN Security Council, the world's only body with the recognized right to use force for reasons beyond legitimate national selfdefense, is necessary from the earliest stages of the conflict-response continuum. This is needed to ensure the development of a common understanding of the problem, which will eventually form the basis for legitimate intervention and use of force.

Addressing the roots of conflict. Conflicts are rooted in resentment and dissatisfaction that become so strong that political extremists find support among peoples who feel excluded from what they feel is their rightful place in the world. Where such conditions exist, they should be addressed through long-term programs of redressment and economic development. This requires a measure of foresight, tolerance, and understanding that the international community, and sovereign governments, have historically had great difficulty mustering. 


\section{Phase 2. Conflict termination: coalitions and zero casualties}

Consolidating conflict coalitions. Once conflicts emerge, they must be terminated with unflinching international political will. Bringing together ad hoc coalitions of the willing to terminate a conflict depends on a common understanding of the risks inherent in the conflict and the possibility of its possible spread. Recognition is needed that world stability is essential to all countries' national interests; this in turn must lead to the logical conclusion that the conflict must be ended in order to restore regional stability. A broad common understanding of the conflict response continuum is also essential at the political level. These elements must be translated into a joint appreciation of the development and implications of the specific conflict being faced.

Casualty-free conflict termination: technologies. Weapons systems must be developed that carry technologies even further than today's state of the art. There must be additional development of unmanned airborne reconnaissance and intelligence-gathering systems that are directly linked in real time to battlefield weapons control teams. The ability to read minute details at a distance, so as to differentiate between potential targets and non-combatants, must be developed much more thoroughly than it is today. Distant intelligence-reading and battlefield management teams must have at their disposal attack systems which can launch pre-programmed, hyper-accurate, pin-point weapons from unmanned platforms without risk to friendly personnel or non-combatants. The technical ability to fight war without sustaining casualties is near at hand, and raising it as a research and development objective will accelerate development of the needed systems. America is the nation most likely to develop or perfect the needed technologies, and must be willing to share them with its allies.

Casualty-free conflict termination: tactics. Non-combatant casualties must be kept to a minimum, but military efforts cannot be precluded because of them. Tactics also need to be refined, based on recent experience, so that intense punishment is carried directly to the headquarters of hostile factions, to force early stand-down, while avoiding wholesale destruction or casualties to friendly or innocent persons. Elimination of warlord leaders must be a key objective, and the tools needed for it need to be available. As frightening as these concepts sound, they are key to the ability to respond effectively to future conflicts.

\section{Phase 3. Post-conflict rehabilitation and exit}

Energetic post-conflict stabilization. This cannot be conceived of simply as peacekeeping. Whatever peacekeeping is required can only be the means that make possible an intense period of society-wide stabilization. This must be prepared in advance, as a cohesive effort. Trained outsiders must enter quickly and substitute for normal governmental services while working with and grooming local replacements. Handing over responsibilities to qualified, newly-trained locals must take 
place as soon as possible. Recent international experience provides some models for such efforts, and includes both good and bad examples of what is needed.

Long-term societal rehabilitation. This must be seen in advance as a very long-term commitment to reshape everything from the legal framework to the political context and the educational curricula used in schools. The objective should be to develop positive approaches based on local cultures, stressing non-violent progress free from long-standing hatreds and vendettas. Specific programs must be developed that will encourage and facilitate business investment and economic development in the post-conflict area, providing an element of hope for a better life. Ten to twenty years would be a typical timeframe for such a reconstruction effort. "Exit" strategies should take account of this long-term obligation. Talking in terms of quick exits is misleading.

All of the measures described above will be difficult, but they are the only real basis for effective response to the "unloved" wars the international community is likely to face in the years ahead. 


\section{Bibliography}

Alexander, Solzhenitzyn. The Gulag Archipelago. New York: Harper and Row, 1974.

Articles of Faith, Articles of Peace: The Religious Liberty Clauses and the American Public Philosophy. Washington, D.C.: The Brookings Institution, 1990.

Bainton, Roland H.. Christian Attitudes Toward War and Peace: A Historical Survey and Critical Reevaluation . Nashville: Abingdon, 1960.

Berman, Harold J.. Law and Revolution: The Formation of the Western Legal Tradition. Cambridge, MA: Harvard University Press, 1983.

Hashmi, Sohail M.. "Interpreting the Islamic Ethics of War and Peace." In The Ethics of War and Peace: Religious and Secular Perspectives. Princeton: Princeton University Press, 1996.

Hobsbawm, Eric. Age of Extremes: The Short Twentieth Century 1914-1991. London: Abacus, 1995.

Johnson, James Turner. Just War Tradition and the Restraint of War: A Moral and Historical Inquiry. Princeton: Princeton University Press, 1981.

Jr., John Witte, and Christian M. Green. "The American Constitutional Experiment in Religious Human Rights: The Perennial Search for Principles." In Religious Human Rights in Global Perspective. The Hague: Martinus Nijhoff Publishers, 1996.

Just War and Jihad: Historical and Theoretical Perspectives on War and Peace in Western and Islamic Tradition . New York: Greenwood Press, 1999.

Just War Theory . Oxford: Blackwell, 1992.

Lonergan, Bernard J.. Insight: A Study of Human Understanding . New York: Longmans, 1958.

McKeon, Richard. "The Philosophic Bases and Material Circumstances of the Rights of Man." In Human Rights: Comments and Interpretations . London: Wingate, 1949.

O'Brien, William V.. The Conduct of War and Limited War . New York: Praeger, 1981.

Perry, Michael J.. The Idea of Human Rights: Four Inquiries. New York: Oxford University Press, 1998.

Peters, Rudolf. Jihad in Classical and Modern Islam . Princeton: Markus Wiener, 1996.

Picco, Giandomenico. "The U.N. and the Use of Force." Foreign Affairs 73 (1994).

Ramsey, Paul. Speak Up for Just War or Pacifism . University Park, PA: Pennsylvania State University Press, 1988.

Walzer, Michael. Just and Unjust Wars. New York: Basic Books, 1977.

War and Morality . Belmont, CA: Wadsworth, 1970. 
Weis, Thomas G., David P. Forsythe, and Roger A. Coate. United Nations and Changing World Politics . Boulder, CO: Westview Press, 2001.

Zawati, Hilmi. Is Jihad a Just War? War, Peace, and Human Rights under Islamic and Public International Law . Lewiston, NY: Edwin Mellen, 2001. 